\title{
EFFECT OF SUPPLEMENTATION OF OREGANO OR NIGELLA SATIVA SEEDS TO DIETS OF LACTATING ZARAIBI GOATS ON MILK YIELD AND SOME PHYSIOLOGICAL FUNCTIONS DURING SUMMER SEASON
}

\author{
S. A. EL-Saadany ${ }^{1}$, A.A.M. Habeeb ${ }^{4}$, E.S. EL-Gohary ${ }^{2}$, M.M. El-Deeb ${ }^{1}$ \\ and K. M. Aiad ${ }^{3}$
}

1- Animal Nutrition Research Department, 2- Sheep and Goat Research Department, 3- Milk Technology Research Department, Animal Production Research Institute, Agriculture Research Center, Ministry of Agriculture, Egypt, 4Biological Applications Department, Radioisotopes Applications Division, Nuclear Research Center, Atomic Energy Organization, Anshas Cairo P.O.13759

\section{SUMMARY}

Twenty one Zaraibi goats, in their $3^{\text {rd }}$ lactation averaging three years of age and $38 \pm 3 \mathrm{~kg}$ weight were divided into three groups. The experiment continued for 25 weeks from May until October to examine the effect of Oregano /Origanum vulgare $(\mathrm{OV})$ or Nigella /Nigella sativa seeds (NSS) as nutritive supplement under hot conditions on milk yield, milk composition, milk physical and chemical properties of curd (the rennet coagulation time "RCT"; cured tension "CT" and whey syneresis), blood Ht\%, Hg, RBC's and WBC's and to estimate immunity, kidney functions, energy metabolites, cholesterol and heart healthy indicators in plasma and some blood minerals and blood serum liver enzymes. Does were fed the control ration, without additives in the $1^{\text {st }}$ group (Control), or with crushed $100 \mathrm{mg} / \mathrm{kg}$ live body weight of does from $\mathrm{OV}$ or NSS in the $2^{\text {nd }}$ and $3^{\text {rd }}$ groups, respectively. The control ration consisted of. $60 \%$ concentrate feed mixture (CFM) plus $40 \%$ rice straw (RS) on DM basis. The results showed that supplementing (suppl.) diets of lactating Zaraibi goats during the summer season with $O V$ and NSS improved $(P<0.05)$ significantly milk yield by $32.1 \%$ and $42.0 \%$, respectively without any adverse effect on milk quality. Milk total solids, protein, fat, lactose and ash percentages were not affected $(P<0.05)$ significantly by suppl. with NSS or OV. The rennet coagulation time, $C T$ and whey syneresis of goats milk raw or pasteurized were not affected by NSS or OV additives. Supplemented diets of lactating goats increased $(P<0.05)$ significantly the $\mathrm{Hg}$ values and $\mathrm{RBC}$ 'S count, respectively, by $21.3 \%$ and $25.1 \%$ for $O V$ and 34.4 and 25.3\% for NSS. Diets supplemented with NSS increased significantly blood concentrations of $\mathrm{Na}, \mathrm{K}, \mathrm{Ca}, \mathrm{P}$ and $\mathrm{Zn}$ of lactating goats. Liver and kidney functions were not affected negatively by either OV or NSS. Moreover, suppl. improved the immunity function i.e. total protein and globulin concentrations and decreased total cholesterol as well as glucose level in the blood plasma.

Keywords: Goats, Oregano, Nigella sativa, heat stress, milk yield, blood profile

\section{INTRODUCTION}

Oregano (OV) has a unique ability to improve many organs functions involved with digestion, blood flow and the rate of heart beat due to its antioxidant activity and

Issued by The Egyptian Society of Animal Production 
its high content of phenolic acids and flavonoids (Bozin et al., 2006). Compounds of OV essential oil that contain rosemarinic, lithospermic acid, carvacrol, thymol, carvacrol, thymol, cis-ocimene, caryophyllene, linalool, oleanolic and ursolic acids, flavonoids, caffeic, , tannins and phenolic glycosides showed antioxidant activity and act similar or better than alpha tocopherol (Ivanova et al., 2005). Oregano inhibited aflatoxin and prevented growth of aspergillus at $0.1 \%$ concentration (Basilico and Basilico, 1999). Oregano essential oil, have completely inhibited fungal growth of aspergillus and penicillium species (Akgul and Kivanc, 1988). It has some antifungal activity against candida species, due to its carvacrol content (Giordani et al., 2004). The volatile oils of OV have demonstrated in vitro antibacterial activity against a wide range of gram-positive and gram-negative microorganisms including Listeria, Pseudomonas, Proteus, Salmonella, Clostridium species (Burt and Reinders, 2003 and Chorianopoulos et.al., 2004) and some methicillin-resistant staphylococci.(Bozin et al., 2006). Oregano phenolic compounds represent $71 \%$ of the total oil. The polar phenols, thymol and carvacrol are responsible for many of the properties of the essential oil, as well as p-cymene and terpinene (Koukoulitsa et al., $2006 \mathrm{a}, \mathrm{b}$ ).

Nigella sativa seeds (NSS) pressed into oil has been traditionally used as treatment for respiratory, stomach, intestine, kidney, liver function, circulatory and immune systems support and for general well-being. Islamic scientist Ibn Sina, told that NSS stimulates the body's energy and helps recovery from fatigue and dispiritedness.

Black seeds or Nigella sativa seeds (NSS) contain high nutritional compounds as mono-saccharides in the form of glucose, rhamnose, xylose, and arabinose. The NSS contains non-starch polysaccharide components which is a useful source of dietary fiber. It is rich in unsaturated and essential fatty acids (Linoleic and Linoleic acid). The NSS contain fifteen amino acids including eight essential amino acids. Black seeds contain Arginine which is essential for infants growth and carotene, which is converted into vitamin A, the vitamin known for its anti-cancer activity. The NSS is also a source of calcium, iron, sodium, and potassium. Black seed oil contains $(1.4 \%)$ Carvone $(21.1 \%)$, Alfa-Pinene $(7.4 \%)$, Sabinene (5.5\%), Beta-Pinene $(7.7 \%)$ Pcymene $(46.8 \%)$ and Others $11.5 \%$.

Approximate chemical analysis and the major effective substances of the NSS are 21.0, 35.5, 34.7, 3.7, 33.0 and $1.5 \%$ for CP, EE, NFE, ash, fixed oils and volatile oils, respectively, according to Ferdous et al. (1992) and Chevallier (1996).

Black seeds contains over 100 components, which are good source of essential fatty acids, proteins, carbohydrates, vitamins $\mathrm{A}, \mathrm{B}_{1}, \mathrm{~B}_{2}, \mathrm{C}$ and niacin as well as minerals such as calcium, potassium, iron, magnesium, selenium, zinc and carotene. Nigella contains $21 \%$ protein, $35 \%$ carbohydrates and $35-38 \%$ fats. Valuable nutrients of NSS oil (Black Cumin or Nigella sativa) are Protein 20.8\%, Thiamin 15, Riboflavin 1, Pyridoxine 5, Niacin $57 \mathrm{ug} / \mathrm{g}$, Folacin $610 \mathrm{IU} / \mathrm{g}$, Calcium (Ca) 1.859 $\mathrm{mg} / \mathrm{g}$, Iron 105, Copper 18, Zinc (Zn) $60 \mathrm{ug} / \mathrm{g}$ and Phosphorus (P) $5.265 \mathrm{mg} / \mathrm{g}$. It is rich in fatty acids, particularly the unsaturated and essential fatty acids (Linoleic and Linolenic acid). The essential fatty Acids contain alpha-Linolenic acid (omega-3) and Linoleic acid (omega-6). Nigella sativa seeds contain 30\% protein (Khalifa, 1995 and Salem and EL-Mahdy, 1999). The crude protein of NSS was 34.00\% (Saad, 2001). Awadalla and Gehad (2003) reported that the composition of DM\% of NSS is 25.51 , 8.54, 43.33, 17.10 and 5.52\% for CP, CF, EE, NFE and Ash, respectively. From another point of view the NSS oils could be used as antioxidant agent as it inhibit the 
non-enzymatic peroxidation (Saad, 2001) which may increase the immunity and help the animals to tolerate the heat stress (Azab Awad-Allah, 2002).

Therefore, the current study aimed to study the effect of OV or NSS as feed additives on milk yield and physiological body functions of lactating Zaraibi goats under hot summer season in Egypt.

\section{MATERIALS AND METHODS}

This study was carried out at El-Serw Experimental Station belonging to the Animal Production Research Institute, Agricultural Research Center, and Ministry of Agriculture at Domiat Governorate during the period from May to October 2007.

\section{1-Experimental animals:}

Twenty one Zaraibi goats, in the third lactation season, averaged three years old and $38 \pm 3 \mathrm{~kg}$ weight were divided into three similar groups, seven does in each. All Does were housed under a semi-roofed yard and kept under the experimental feeding and same managerial conditions. Animals were weighed individually at the beginning and bi-weekly intervals to evaluate changes of live body weight of does.

\section{2-Experimental feeding:}

The experiment lasted for 25 weeks; animals were fed for two weeks at the beginning on the tested rations as a transitional period. Does of all groups were fed a control ration consisted of $60 \%$ concentrate feed mixture (CFM) plus $40 \%$ rice straw (RS) on DM basis according to allowances of NRC (1981) of milking goats. Does in the $1^{\text {st }}$ group were fed the basal ration without additives as control ration $(\mathrm{CR})$, while those in the $2^{\text {nd }}$ and $3^{\text {rd }}$ groups were fed the same basal ration supplemented with crushed $100 \mathrm{mg} / \mathrm{I} \mathrm{kg}$ of does live body weight, respectively from Oregano /Origanum vulgare (OV) or Nigella /Nigella sativa seed (NSS) according to Chevallier (1996). The CFM consisted of $37.5 \%$ wheat bran, $27 \%$ yellow corn, $12.5 \%$ soybean meal ( $44 \% \mathrm{CP}), 10.0 \%$ un-decorticated cottonseed cake, $5 \%$ rice bran, $4 \%$ sugarcane molasses, 3\% limestone and 1\% sodium chloride. Feed additives were mixed manually with some fine CFM, mixed with the concentrated meals twice daily. Rations were offered in group feeding to does of each group twice daily at 8 am and $4 \mathrm{pm}$. Fresh drinking water, minerals and vitamins blocks were available for free choice. Samples of feeds were analyzed according to A.O.A.C. (1995).

\section{3- Chemical analysis:}

Milk: The daily milk yield was recorded from each goat at the evening milking and the next morning milking. Daily milk yield was measured, monthly and total milk yield $(\mathrm{kg})$ were estimated. Composite milk samples were collected one day monthly from all experimental goats and freezed immediately $\left(-20{ }^{\circ} \mathrm{C}\right)$ till analyzed. for total solids, protein, fat, lactose and ash in $\mathrm{g} / 100 \mathrm{ml}$ milk using Milko Scan mark (, 133 B, N. FOSS, Electric, Den mark. Percentages of total solids (TS), total protein, fat and ash were determined by the methods of Ling (1963). Lactose content was determined according to Barnett and Abd El-Tawab (1957). Ash content was determined as reported in A.O.A.C. (1984). 


\section{4- Milk acidity and $\mathrm{PH}$ development:}

Fresh whole goat's milk of different treatments was divided into two parts. The first part was incubated at $30^{\circ} \mathrm{C}$ for 5 hours. The second part was heated at $90^{\circ} \mathrm{C}$ for 15 sec., cooled to $30^{\circ} \mathrm{C}$, then was subdivided into two portions; the first was inoculated with $1 \%$ yoghurt starter culture and the second portion was inoculated with $1 \%$ pure culture of Lactococcus Lactis subsp. Lactis. . The second parts was incubated at $30^{\circ} \mathrm{C}$ for 5 hs.

\section{5- Rheological properties of curd:}

Rennet coagulation time (RCT) was measured by Davies and White (1958). Tension was estimated as described by Chandrosekhara et al. (1975). The rate of whey syneresis of fresh curd was measured as the volume of drained whey after 10 , $30,60,90 \mathrm{~min}$, it was calculated as a percent of the volume of milk according to Lawernce (1959).

\section{6- Blood samples:}

Blood sampling were taken monthly from the jugular vein with anticoagulant to determine hematocrite $(\mathrm{Ht}) \%$, hemoglobin $(\mathrm{Hg})$, red blood corpuscles (RBC's) and white blood corpuscles (WBC's) in the whole blood samples immediately after blood samples collection. Then the residual blood samples were centrifuged at $2000 \mathrm{xg}$ for 25 minutes to obtain plasma. Immunity function (total protein, albumin and globulin), kidney function (creatinine and urea-N), energy metabolites (glucose, total lipids), Cholesterol and coronary heart disease or heart healthy (triglycerides and cholesterol) and some minerals ( $\mathrm{Na}, \mathrm{K}, \mathrm{Ca}, \mathrm{Mg}, \mathrm{Pi}$, and $\mathrm{Zn}$ concentrations) were estimated in the plasma using commercial chemical reagent kits. In addition, liver function (AST, ALT and Alk-P enzyme activities) was also estimated in serum of samples which were collected without anticoagulant and centrifuged at $2000 \mathrm{xg}$ for 25 minutes. Blood analysis was conducted in the Bioclimatology Unit, Department of Radioisotopes Applications, Radioisotopes Applications Division, Nuclear Research Center, Atomic Energy Authority, Inshas, Cairo, Egypt.

\section{7-Meteorological data and temperature humidity index (THI) estimation:}

Air temperature $\left({ }^{\circ} \mathrm{F}\right)$ and relative humidity $(\%)$ inside the farming building were measured once a day weekly four times at 12.00, 13.00, 14.00 and 15.00 hours using digital thermo hygrometer. Temperature-humidity index (THI) values were calculated according to The Livestock and Poultry Heat Stress Indices for Cattle, Sheep and Goats (1990) cited from Agriculture Engineering Technology Guide, Clemson University, Clemson, SC 29634. USA (1990). The THI values indicated that Zraibi goats suffering from very severe heat stress conditions from June to October months in El-Serw Experimental Station at Domiat Governorate (Habeeb et al. (2008).

\section{8 - Statistical analysis:}

The data of present study were statistically analyzed using general linear model procedure by computer program of SAS (1995) and the statistical model was as follows:

$\mathrm{Y}_{\mathrm{ij}}=\mu+\mathrm{T}_{\mathrm{i}}+\mathrm{Mj}+\mathrm{T} \times \mathrm{FLij}+\mathrm{e}_{\mathrm{ij}}$ 
Where $Y_{i j}=$ the observation, $\mu=$ overall mean, $T_{i}=$ the fixed effect of treatments, $\mathrm{Mj}$ $=$ the fixed effect of month, $\mathrm{T} \times \mathrm{M}=$ the fixed effect of interactions between treatments and year month and eij = the random error according to Snedecor and Cochran (1982). Duncan's Multiple Range Test (Duncan, 1955) was used for testing the significant differences between means.

\section{RESULTS AND DISCUSSION}

Effect of Oregano and Nigella sativa seeds on milk yield and composition:

Results showed that supplemented diets of lactating Zaraibi goats with OV or NSS during summer season improved $(\mathrm{P}<0.05)$ significantly milk yield by 32.1 and $42.0 \%$, respectively than CR, with better results for NSS than OV. Milk fat (MF) and milk total solids (TS) percentages of Zaraibi goats increased progressively $(\mathrm{P}<0.05)$ during lactation stage, especially at the last three months. On the other hand, the percentages of TS, protein (P), MF, lactose (L) and ash of milk were not affected significantly $(\mathrm{P}<0.05)$ due to feed additives to lactating does during summer season as shown in Table 1.

Table 1. Effect of Oregano or Nigella sativa seeds in diet of lactating Zraibi Goats on daily and monthly milk yield and milk composition

\begin{tabular}{|c|c|c|c|c|c|c|c|c|}
\hline Milk yield & $\begin{array}{l}\text { Experimental } \\
\text { Groups }\end{array}$ & May & June & July & Aug. & Sep. & Oct. & $\begin{array}{l}\text { Mean } \\
\text { of } 6 \\
\text { months }\end{array}$ \\
\hline \multirow{3}{*}{$\begin{array}{l}\text { Daily milk } \\
\text { yield, kg }\end{array}$} & Control & $1.45^{\mathrm{a}}$ & $1.36^{\mathrm{b}}$ & $1.19^{\mathrm{c}}$ & $0.87^{\mathrm{d}}$ & $0.76^{\mathrm{d}}$ & $0.12^{\mathrm{e}}$ & $0.96^{\mathrm{B}}$ \\
\hline & Oregano & $1.89^{\mathrm{a}}$ & $1.76^{\mathrm{b}}$ & $1.43^{\mathrm{c}}$ & $1.32^{\mathrm{d}}$ & $1.03^{\mathrm{e}}$ & $0.18^{\mathrm{f}}$ & $1.27^{\mathrm{A}}$ \\
\hline & Nigella & $2.10^{\mathrm{a}}$ & $1.85^{\mathrm{b}}$ & $1.49^{\mathrm{c}}$ & $1.35^{\mathrm{d}}$ & $1.17^{\mathrm{e}}$ & $0.21^{\mathrm{f}}$ & $1.36^{\mathrm{A}}$ \\
\hline \multirow{3}{*}{$\begin{array}{l}\text { Monthly } \\
\text { milk yield, } \\
\text { kg }\end{array}$} & Control & $45.0^{\mathrm{a}}$ & $40.7^{\mathrm{b}}$ & $37.0^{\mathrm{bc}}$ & $27.1^{\mathrm{cd}}$ & $22.9^{d}$ & $3.7^{\mathrm{e}}$ & $29.40^{\mathrm{B}}$ \\
\hline & Oregano & $58.6^{\mathrm{a}}$ & $52.8^{\mathrm{b}}$ & $44.3^{\mathrm{c}}$ & $40.8^{\mathrm{c}}$ & $30.8^{d}$ & $5.7^{\mathrm{e}}$ & $38.83^{\mathrm{A}}$ \\
\hline & Nigella & $65.1^{\mathrm{a}}$ & $55.6^{\mathrm{b}}$ & $46.2^{\mathrm{c}}$ & $41.9^{\text {cd }}$ & $35.2^{\mathrm{d}}$ & $6.5^{\mathrm{e}}$ & $41.75^{\mathrm{A}}$ \\
\hline \multicolumn{9}{|c|}{ Milk composition } \\
\hline \multirow{4}{*}{$\begin{array}{l}\text { Total } \\
\text { solids }\end{array}$} & Control & $12.0^{\mathrm{d}}$ & $12.10^{\mathrm{d}}$ & $12.30^{\mathrm{c}}$ & $12.35^{\mathrm{c}}$ & $12.70^{\mathrm{b}}$ & $13.30^{\mathrm{a}}$ & 12.45 \\
\hline & Oregano & $11.9^{\mathrm{d}}$ & $12.09^{\mathrm{d}}$ & $12.34^{\mathrm{c}}$ & $12.38^{\mathrm{c}}$ & $12.63^{\mathrm{b}}$ & 13.46 & 12.47 \\
\hline & Nigella & $12.1^{\mathrm{d}}$ & $12.12^{\mathrm{d}}$ & $12.35^{\mathrm{c}}$ & $12.40^{\mathrm{c}}$ & $12.80^{\mathrm{b}}$ & & 12.55 \\
\hline & & & & & & & $13.60^{\mathrm{a}}$ & \\
\hline \multirow{4}{*}{ Protein } & Control & 2.86 & 2.85 & 2.83 & 2.90 & 2.97 & 2.98 & 2.90 \\
\hline & Oregano & 2.76 & 2.83 & 2.86 & 2.86 & 2.89 & 2.99 & 2.87 \\
\hline & Nigella & 2.87 & 2.80 & 2.80 & 2.87 & 2.99 & 2.96 & 2.88 \\
\hline & Control & $3.8^{\mathrm{d}}$ & $3.93^{\mathrm{d}}$ & $4.13^{\mathrm{c}}$ & $4.11^{\mathrm{c}}$ & $4.38^{\mathrm{b}}$ & $4.96^{\mathrm{a}}$ & 4.23 \\
\hline \multirow[t]{2}{*}{ Fat } & Oregano & $3.8^{\mathrm{d}}$ & $3.94^{\mathrm{d}}$ & $4.15^{\mathrm{c}}$ & $4.15^{\mathrm{c}}$ & $4.42^{\mathrm{b}}$ & $5.09^{\mathrm{a}}$ & 4.27 \\
\hline & Nigella & $3.9^{\mathrm{d}}$ & $4.01^{\mathrm{d}}$ & $4.18^{\mathrm{c}}$ & $4.16^{\mathrm{c}}$ & $4.49^{\mathrm{b}}$ & $5.29^{\mathrm{a}}$ & 4.34 \\
\hline \multirow{3}{*}{ Lactose } & Control & 4.541 & 4.60 & 4.61 & 4.60 & 4.60 & 4.60 & 4.59 \\
\hline & Oregano & 4.58 & 4.60 & 4.60 & 4.63 & 4.60 & 4.62 & 4.61 \\
\hline & Nigella & 4.56 & 4.58 & 4.63 & 4.64 & 4.59 & 4.61 & 4.60 \\
\hline \multirow{3}{*}{ Ash } & Control & 0.73 & 0.72 & 0.73 & 0.74 & 0.75 & 0.76 & 0.74 \\
\hline & Oregano & 0.72 & 0.73 & 0.73 & 0.74 & 0.72 & 0.76 & 0.73 \\
\hline & Nigella & 0.72 & 0.73 & 0.74 & 0.73 & 0.73 & 0.74 & 0.73 \\
\hline
\end{tabular}


In addition, dams' weights during experimental period were higher in the lactating Zaraibi goats supplemented with OV or NSS in their diet than that of the CR which was free from additives (Fig. 2). From other point of view averages of daily and monthly milk yield of goats decreased progressively $(\mathrm{P}<0.05)$ from May to October as shown in Table 1 and Fig.1.
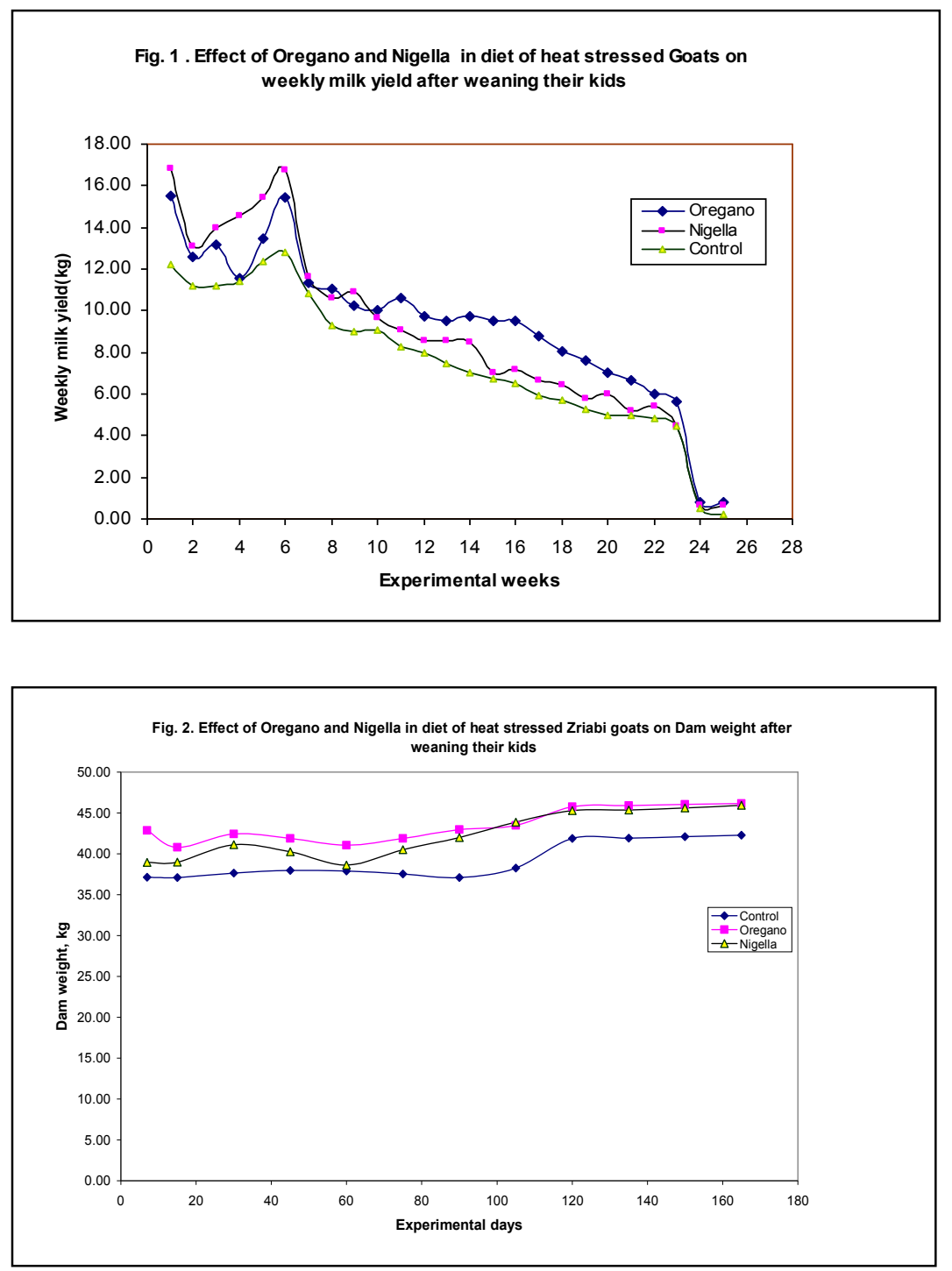

Results agree with Allam et al. (1999) who observed that adding NSS to dairy goat diets had a positive effect on milk production and feed efficiency. Allam et al. 
(2007) also found that ration of lactating goats, supplemented with $0.25 \mathrm{~g}$ NSS powder / $\mathrm{kg} \mathrm{LBW} \mathrm{/day} \mathrm{improved} \mathrm{significantly}(\mathrm{P}<0.05)$ litters weight during suckling period and at weaning age ( 90 days) in Zaraibi kids. The same study reported that feed efficiency as g gain/ $\mathrm{g}$ DM or TDN increased significantly $(\mathrm{P}<0.05)$ due to the treatment. Mohamed et al. (2003) reported that supplementing feeds by $100 \mathrm{mg}$ NSS $/ 1 \mathrm{~kg}$ LBW of ewes improved significantly the feed intake and the digestibility coefficient of DM, OM, CP, CF and NFE and nutritive values as TDN, SE and DCP.

At other point of view EL-Gendy et al. (2001) found that replacement of NSS instead of other meal protein in Rahmany rams rations improved DM, OM, CF and GE digestibilities significantly $(\mathrm{P}<0.05)$ than for other rations. The authors reported that DE and TDN of rations containing NSS were higher than that of other rations, concluding that NSS could be used successfully in ruminant rations to improve its nutrients digestibility coefficients and nutritive values.

Agarwhal et al. (1979) found that NSS oil increased the milk output of breast feeding mothers and revealed that NSS capacity to increase the milk flow of nursing mothers could be attributed to a combination of lipid portion and hormonal structures found in the black seeds.

\section{Milk acidity development and $\mathrm{pH}$ changes :}

Table (2) revealed increased acid development for raw goat's milk and milk inoculated with yoghurt and lactococcus lactis subs. Lactis for all treatment groups. Therefore, this development in acidity proved that goats' milk of different treatments is proper for manufacturing some fermented dairy products such as cheese, yoghurt and cultured milk. These results are in agreement with those of Enab (1993) and Ayad (2003). In the same time, natural milk pH and $\mathrm{pH}$ of milk inoculated with the used starters were decreased along with incubation period. This observation proved the suitability of goats' milk for growth and biochemical activity of starter microorganisms. These results are in agreement with those of Youssef (1989) and ElAlamy et al. (1991) .

\section{Some rheological properties of milk:}

The fresh whole goats' milk of different treatment groups were divided into two sections; the first section included the fresh whole raw goats' milk heated to $30^{\circ} \mathrm{C}$ and rennet was added. The second section included whole goats' milk of all treatments groups was heated to $72^{\circ} \mathrm{C}$ cooled to $30^{\circ} \mathrm{C}$ and $1 \%$ pure cultures of lactococcus lacits subsp. lactis was added to it. From table (3) there was no significant variation among different treatment groups in the first section as regard (RCT) while in the second section 2 (RCT) was 210 minutes for all treatment groups. This may be due to the effect of the starter on acidity development provided in the formed cured .Concerning curd tension (CT) and whey syneresis the raw goats' milk (first section) showed higher values than when starter was added (second section). These differences may be due to increased protein content of goats' milk as affected by acidity of milk and curd (Dimov and Mineva, 1963). The percentage of fat loss in the whey were approximately similar in the treatment of the two sections. These results were in agreement with those obtained by Emara (1990), El-Alamy et al. (1992), Enab (1993) and Mehana et al. (1998) . 
Table 2. Acidity and pH developments of goat's milk inoculated with some starters

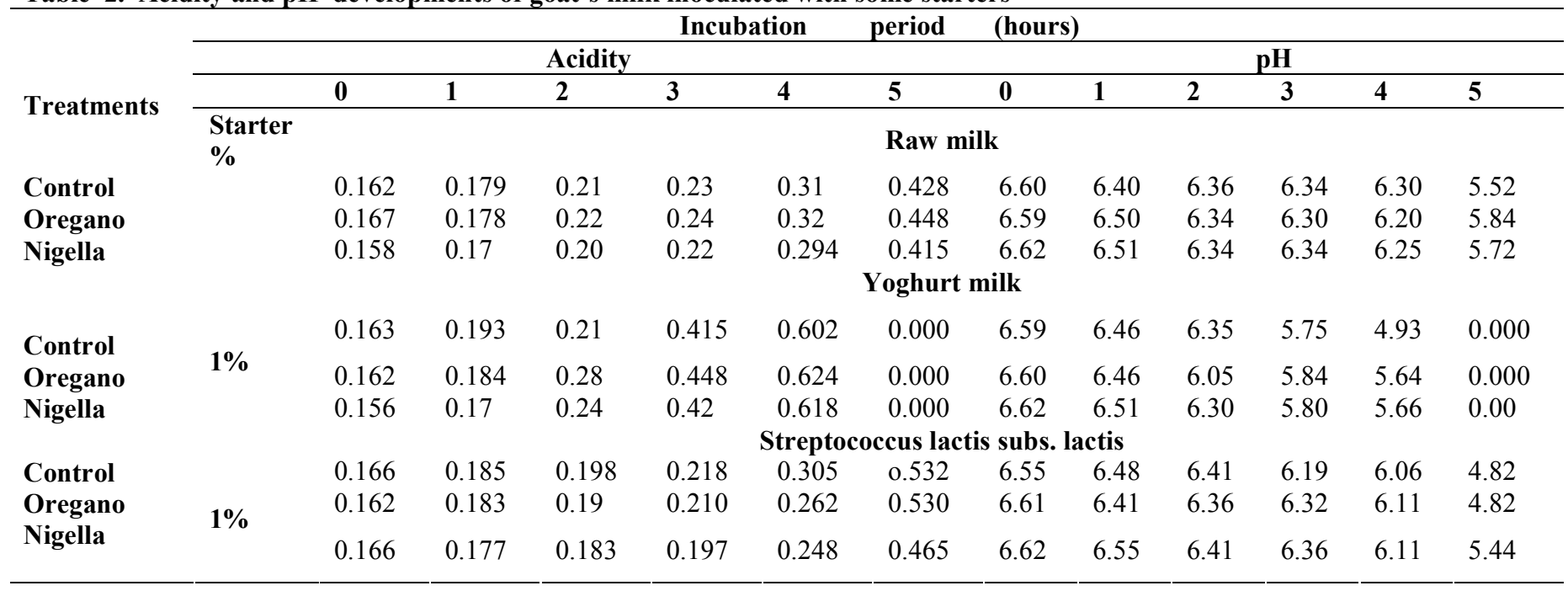


Table 3. Effect of different rations on RCT, CT, whey syneresis and fat loss of whey in goat's milk

\begin{tabular}{|c|c|c|c|c|c|c|c|c|}
\hline \multirow[b]{2}{*}{ Treatment } & \multirow[b]{2}{*}{ Groups } & \multirow{2}{*}{$\begin{array}{l}\text { RCT } \\
\text { min: sec }\end{array}$} & \multirow{2}{*}{$\begin{array}{l}\text { CT } \\
\text { gram }\end{array}$} & \multicolumn{5}{|c|}{ Whey syneresis (after min.) (milli/100ml) } \\
\hline & & & & 10 & 30 & 60 & 90 & $\begin{array}{l}\text { Fat loss of } \\
\text { hey } \%\end{array}$ \\
\hline \multirow{3}{*}{ Section 1} & Control & $2: 42$ & 36.732 & 25.07 & 35.656 & 45.010 & 55.59 & 0.55 \\
\hline & Oregano & $2: 30$ & 41.434 & 25.008 & 35.816 & 44.710 & 55.91 & 0.55 \\
\hline & Nigella & $2: 47$ & 35.732 & 27.03 & 38.30 & 47.110 & 57.52 & 0.5 \\
\hline \multirow{3}{*}{ Section 2} & control & $210: 0$ & 25.577 & 18 & 25 & 30 & 38 & 0.55 \\
\hline & Oregano & $210: 0$ & 28.467 & 21 & 29 & 35 & 42 & 0.55 \\
\hline & Nigella & $210: 0$ & 27.366 & 19 & 26 & 30 & 37 & 0.55 \\
\hline
\end{tabular}

RCT : Rennet Coagulation time

CT : Curd Tension

Blood picture:

Results showed that supplementing OV or NSS to diets of lactating Zaraibi goats during summer season increased significantly $(\mathrm{P}<0.05)$ each of hemoglobin $(\mathrm{Hg})$ values and red blood corpuscles (RBC's) counts by 21.3 and $25.1 \%$ due to OV supplement and 34.4 and $25.3 \%$ due to NSS supplement, respectively than CR. Meanwhile hematocrit $(\mathrm{Ht})$ ratio values and white blood corpuscles WBC's count values didn't affected significantly (Table 4). Regardless adding OV or NSS or not, $\mathrm{Ht}$ values were better in the last three months of the experiment than the first three months. The same trend was observed with RBC's counts for goats fed supplemented rations only which mean permanent improvement in RBC's counts with NSS's suppl. rations. Nair et al., 1991 explained that NSS reduces the toxicity of cisplatin that induced fall in leucocytes count, $\mathrm{Hg}$ levels and osmotic fragility of erythrocytes and also prevent the increase in $\mathrm{Ht}$.

\section{Liver and kidney functions and plasma glucose concentration:}

Important body physiological functions containing liver function presented as AST, ALT and Alk-P enzymes values and kidney functions presented as creatinine and urea-N concentrations were not negatively or significantly $(\mathrm{P}<0.05)$ affected by supplementing OV or NSS to the diet of lactating Zaraibi goats during summer season. The previous parameters and glucose levels were higher in the last three months of the experiment than during the first three months but they were within the normal range (Table 5). However, glucose concentration decreased significantly $(\mathrm{P}<0.05)$ due to NSS supplement by $16.6 \%$ (Table 5), this may be due to NSS stimulation effect for insulin secretion from $\beta$-Langerhanse cells in the pancreas . 
Table 4 - Effect of OV or NSS in diets of lactating Zraibi Goats during summer season on blood profile parameters

\begin{tabular}{|c|c|c|c|c|c|c|c|c|}
\hline \multirow{2}{*}{$\begin{array}{l}\text { Blood } \\
\text { Profile }\end{array}$} & \multirow{2}{*}{$\begin{array}{l}\text { Experimental } \\
\text { groups }\end{array}$} & \multicolumn{7}{|c|}{ Experimental months } \\
\hline & & May & June & July & Aug. & Sep. & Oct. & $\begin{array}{l}\text { Mean of } 6 \\
\text { months }\end{array}$ \\
\hline \multirow{4}{*}{$\mathrm{Ht}, \%$} & Control & $32.0^{\mathrm{b}}$ & $29.5^{\mathrm{b}}$ & $31.3^{\mathrm{b}}$ & $38.8^{\mathrm{a}}$ & $37.8^{\mathrm{a}}$ & $39.0^{\mathrm{a}}$ & 34.72 \\
\hline & Oregano & $30.8^{\mathrm{b}}$ & $28.8^{\mathrm{b}}$ & $35.4^{\mathrm{b}}$ & $37.4^{\mathrm{a}}$ & $38.3^{\mathrm{a}}$ & $37.3^{\mathrm{a}}$ & 34.63 \\
\hline & Nigella & $33.5^{\mathrm{b}}$ & $30.3^{\mathrm{b}}$ & $34.2^{\mathrm{b}}$ & $40.3^{\mathrm{a}}$ & $39.0^{\mathrm{a}}$ & $41.0^{\mathrm{a}}$ & 36.38 \\
\hline & Control & 9.70 & 9.95 & 9.48 & 9.150 & 9.25 & 9.30 & $9.47^{\mathrm{C}}$ \\
\hline \multirow{2}{*}{$\mathrm{Hg}, \mathrm{g} / \mathrm{dl}$} & Oregano & 11.33 & 11.73 & 11.75 & 11.33 & 11.50 & 11.27 & $11.49^{\mathrm{B}}$ \\
\hline & Nigella & 12.85 & 12.88 & 12.35 & 12.90 & 12.78 & 12.70 & $12.73^{\mathrm{A}}$ \\
\hline \multirow[t]{3}{*}{ WBCS, $\mathrm{X} 10^{3}$} & Control & 10.24 & 10.44 & 10.01 & 10.42 & 11.07 & 11.48 & 10.61 \\
\hline & Oregano & 10.84 & 10.20 & 11.33 & 11.07 & 11.18 & 11.12 & 10.96 \\
\hline & Nigella & 10.72 & 10.68 & 10.95 & 10.90 & 11.44 & 11.12 & 10.97 \\
\hline \multirow[t]{3}{*}{ RBCS, $\times 10^{6}$} & Control & 4.98 & 4.59 & 4.86 & 4.03 & 4.87 & 4.40 & $4.62^{\mathrm{B}}$ \\
\hline & Oregano & $5.78^{\mathrm{ab}}$ & $5.47^{\mathrm{b}}$ & $5.50^{\mathrm{b}}$ & $5.82^{\mathrm{a}}$ & $5.95^{\mathrm{a}}$ & $6.13^{\mathrm{a}} \pm$ & $5.78^{\mathrm{A}}$ \\
\hline & Nigella & $5.21^{\mathrm{b}}$ & $5.70^{\mathrm{ab}}$ & $5.32^{\mathrm{b}}$ & $6.27^{\mathrm{a}}$ & $6.06^{\mathrm{a}}$ & $6.18^{\mathrm{a}}$ & $5.79^{\mathrm{A}}$ \\
\hline \multicolumn{9}{|l|}{ Protein fractions } \\
\hline \multirow[t]{3}{*}{ Total Protein, g/dl } & Control & $7.80^{\mathrm{ab}}$ & $7.18^{\mathrm{b}}$ & $7.60^{\mathrm{b}}$ & $8.45^{\mathrm{a}}$ & $8.19^{\mathrm{ab}}$ & $8.50^{\mathrm{a}}$ & $7.96^{\mathrm{C}}$ \\
\hline & Oregano & $8.49^{\mathrm{b}}$ & $8.70^{\mathrm{b}}$ & $8.63^{\mathrm{b}}$ & $9.11^{\mathrm{a}}$ & $9.31^{\mathrm{a}}$ & $9.07^{\mathrm{a}}$ & $8.88^{\mathrm{B}}$ \\
\hline & Nigella & $8.86^{\mathrm{b}}$ & $8.87^{\mathrm{b}}$ & $8.83^{\mathrm{b}}$ & $9.81^{\mathrm{a}}$ & $9.50^{\mathrm{a}}$ & $9.98^{\mathrm{a}}$ & $9.31^{\mathrm{A}}$ \\
\hline \multirow[t]{3}{*}{ Albumin, $\mathrm{g} / \mathrm{dl}$} & Control & $3.82^{\mathrm{b}}$ & $3.60^{\mathrm{b}}$ & $3.80^{\mathrm{b}}$ & $4.41^{\mathrm{a}}$ & $4.32^{\mathrm{a}}$ & $4.40^{\mathrm{a}}$ & 4.06 \\
\hline & Oregano & $3.71^{b} 0$ & $4.50^{\mathrm{a}}$ & $4.10^{\mathrm{a}}$ & $3.89^{\mathrm{ab}}$ & $3.94^{\mathrm{ab}}$ & $3.90^{\mathrm{ab}}$ & 4.01 \\
\hline & Nigella & $3.94^{\mathrm{b}}$ & $4.60^{\mathrm{a}}$ & $4.00^{\mathrm{b}}$ & $3.94^{\mathrm{b}}$ & $3.92^{\mathrm{b}}$ & $3.98^{\mathrm{b}}$ & 4.06 \\
\hline \multirow[t]{3}{*}{ Globulin, g/ dl } & Control & $3.98^{\mathrm{ab}}$ & $3.58^{\mathrm{b}}$ & $3.80^{\mathrm{ab}}$ & $4.04^{\mathrm{a}} 3$ & $3.87^{\mathrm{ab}}$ & $4.10^{\mathrm{a}}$ & $3.90^{\mathrm{C}}$ \\
\hline & Oregano & $4.78^{\mathrm{b}}$ & $4.20^{\mathrm{b}}$ & $4.53^{\mathrm{b}}$ & $5.22^{\mathrm{a}}$ & $5.37^{\mathrm{a}}$ & $5.17^{\mathrm{a}}$ & $4.87^{\mathrm{B}}$ \\
\hline \multirow{2}{*}{\multicolumn{9}{|c|}{ Lipid fractions }} \\
\hline & & & & & & & & \\
\hline \multirow{3}{*}{$\begin{array}{l}\text { Total Lipids, } \\
\mathrm{mg} / \mathrm{dl}\end{array}$} & Control & $5.22^{\mathrm{b}}$ & $4.65^{\mathrm{c}}$ & $5.10^{\mathrm{b}}$ & $6.74^{\mathrm{a}}$ & $6.51^{\mathrm{a}}$ & $6.79^{\mathrm{a}}$ & 5.84 \\
\hline & Oregano & $4.93^{\mathrm{c}}$ & $4.48^{\mathrm{c}}$ & $5.90^{\mathrm{b}}$ & $6.43^{\mathrm{a}}$ & $6.62^{\mathrm{a}}$ & $6.40^{\mathrm{a}}$ & 5.79 \\
\hline & Nigella & $5.55^{\mathrm{c}}$ & $4.82^{\mathrm{d}}$ & $5.70^{\mathrm{c}}$ & $6.08^{\mathrm{b}}$ & $6.79^{\mathrm{ab}}$ & $7.20^{\mathrm{a}}$ & 5.36 \\
\hline \multirow{3}{*}{$\begin{array}{l}\text { Triglycerides, } \\
\text { mg/dl }\end{array}$} & Control & $102.3^{\mathrm{b}}$ & $94.3^{\mathrm{b}}$ & $99.9^{\mathrm{b}}$ & $124.0^{\mathrm{a}}$ & $120.6^{\mathrm{a}}$ & $124.6^{\mathrm{a}}$ & 110.9 \\
\hline & Oregano & $98.26^{\mathrm{ab}}$ & $91.8^{\mathrm{b}}$ & $113.0^{\mathrm{a}}$ & $119.5^{\mathrm{a}}$ & $122.2^{\mathrm{a}}$ & $119.0^{\mathrm{a}}$ & 110.6 \\
\hline & Nigella & $107.1^{\mathrm{b}}$ & $96.7^{\mathrm{b}}$ & $109.3^{\mathrm{b}}$ & $128.8^{\mathrm{a}}$ & $124.6^{\mathrm{a}}$ & $131.0^{\mathrm{a}}$ & 116.2 \\
\hline \multirow[t]{3}{*}{ Total cholesterol, mg/dl } & Control & 131.1 & 131.5 & 138.3 & 146.7 & 142.7 & 147.5 & $131.3^{\mathrm{A}}$ \\
\hline & Oregano & 106.3 & 108.7 & 103.8 & 111.4 & 114.6 & 110.8 & $109.3^{\mathrm{B}}$ \\
\hline & Nigella & 106.7 & 104.4 & 109.3 & 112.4 & 117.5 & 115.0 & $110.9^{\mathrm{B}}$ \\
\hline
\end{tabular}

${ }^{\circ}$ Means in the same raw of each item with different superscript differ significantly at $\mathrm{P}<0.05$.

${ }^{\mathrm{B}}$ Means in the same column of each item in overall mean with different superscript differ significantly at $\mathrm{P}<0.05$ 
Table 5. Effect of Oregano or Nigella sativa in diets of lactating Zraibi Goats during summer hot season on plasma Liver and kidney functions

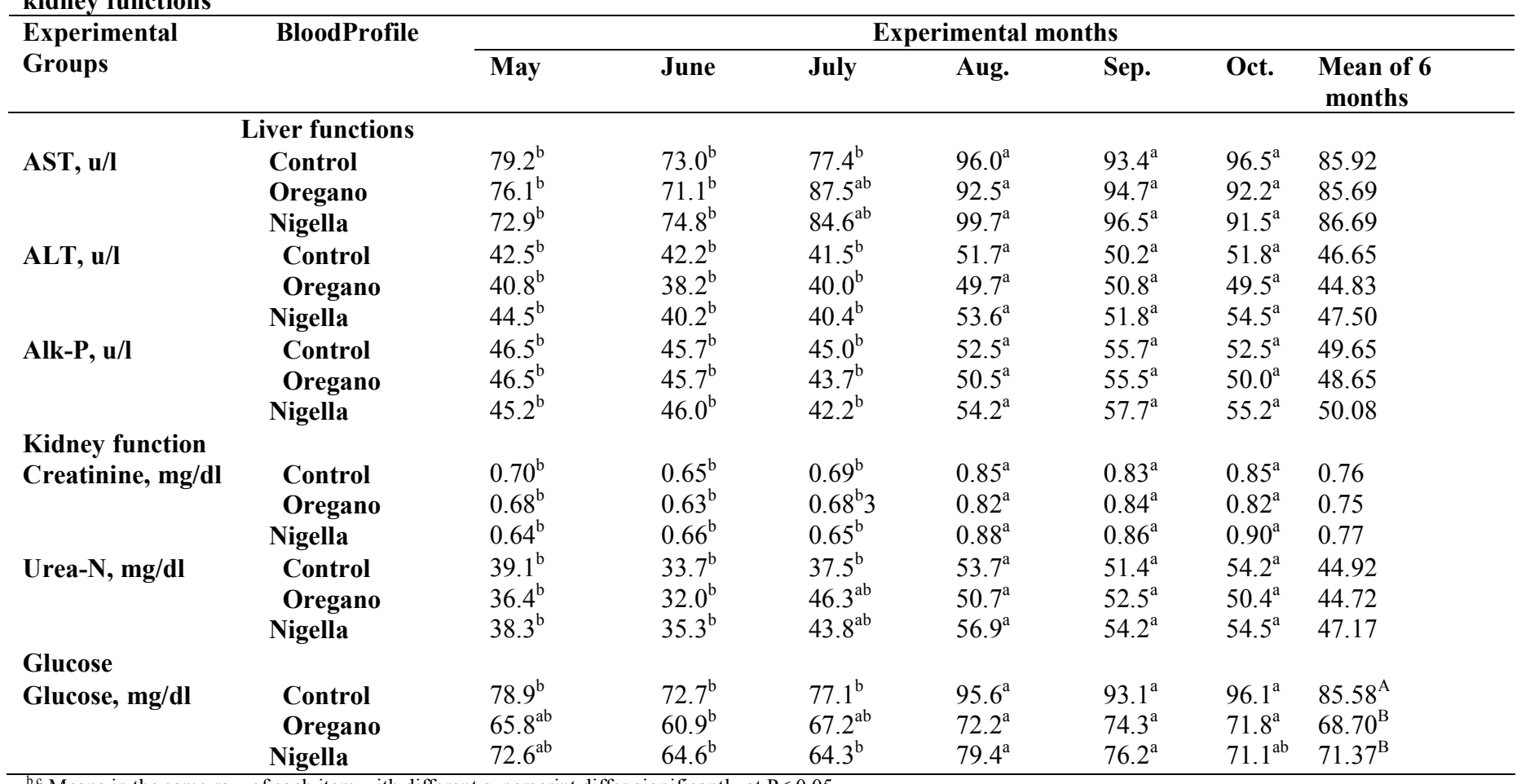

${ }_{, b, c}$ Means in the same raw of each item with different superscript differ significantly at $\mathrm{P}<0.05$

${ }^{\mathrm{B}}$ Means in the same column of each item in overall mean with different superscript differ significantly at $\mathrm{P}<0.05$. 
Table 6. Effect of Oregano or Nigella in diet of lactating Zraibi Goats during months of summer hot season on plasma content of minerals

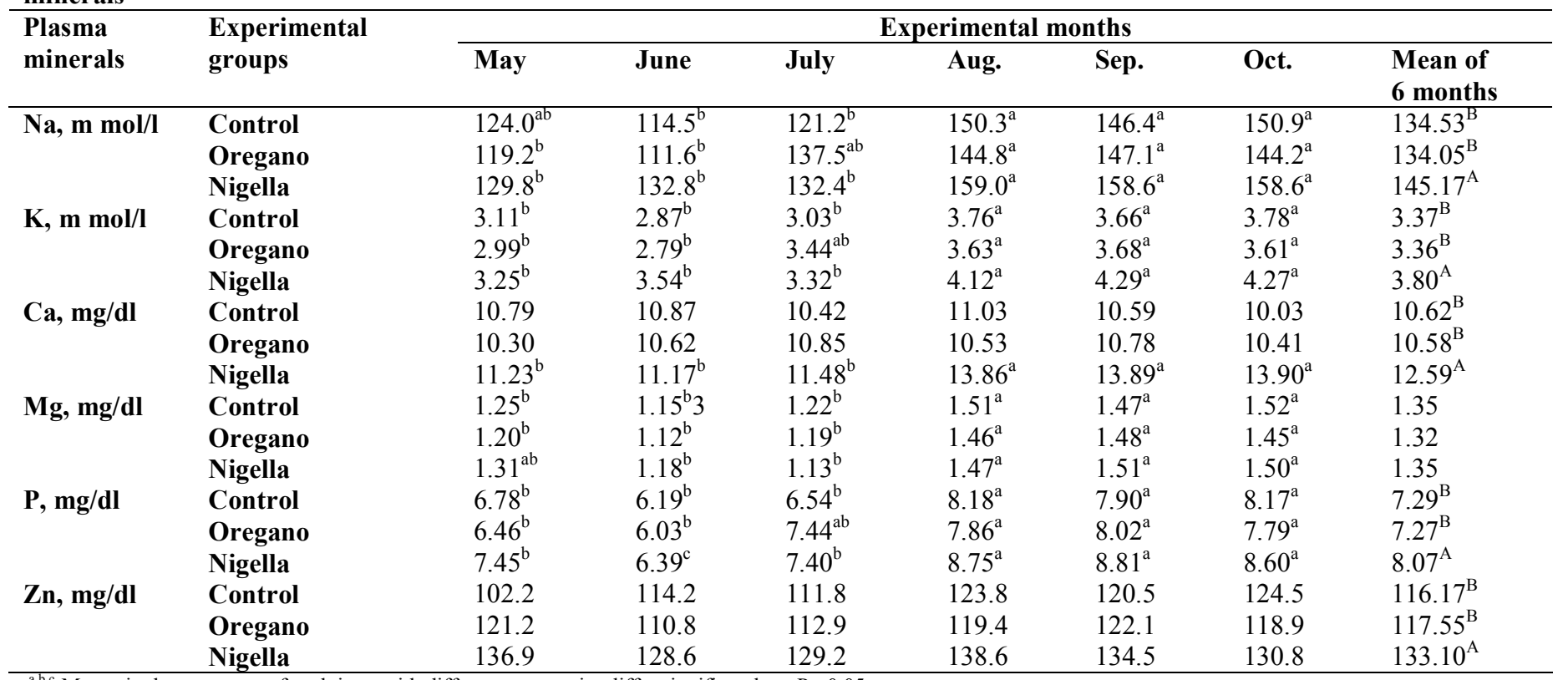

${ }^{a, b, c}$ Means in the same raw of each item with different superscript differ significantly at $\mathrm{P}<0.05$.

$\mathrm{A}, \mathrm{B}$ Means in the same column of each item in overall mean with different superscript differ significantly at $\mathrm{P}<0.05$. 
These results are in harmony with Lemhadri et al., 2004 who demonstrated the hypoglycemic effect of $\mathrm{OV}$ in rats by suggesting a stimulating effect on pancreas for more insulin secretion. This effect occurred after a single dose as well as with repeated daily dosing. Other researchers demonstrated an aldose reductase inhibitor effect by lithospermic and rosmarinic acid extracted from OV. Some researchers suggested that inhibiting the accumulation of sorbitol may contribute to prevention of chronic complications, such as retinopathy and peripheral neuropathy in diabetic patients (Koukoulitsa et al., 2006,a,b).

From other side Daly, 1998 mentioned that NSS combinations with cisplatin partially prevented many undesired changes in the activities of serum enzymes. On contrary with these results Mohamed et al. (2003) reported that AST enzyme activity and urea-N level increased significantly due to rations of ewes supplemented with NSS. Meanwhile Azab Awad-Allah (2002) reported that concentrations of urea and glucose were not affected significantly due to NSS supplement at the rate of 100 $\mathrm{mg} / \mathrm{kg}$ body weight in Friesian calves under heat stress conditions. In agreement with the study results Awad-Allah and Gehad (2003) found that supplementing rations of growing sheep with 1 or $2 \%$ NSS didn't adversely affected the liver function as ALT and AST significantly $(\mathrm{P}<0.05)$. In the same trend Salem and El-Mahdy (1999) reported that creatinine concentration in the blood plasma of the Ossimi lambs was not affected significantly due to supplementing the ration with NSS.

\section{Plasma protein and lipid fractions:}

Results cleared that supplementing diets of lactating Zaraibi goats during hot summer season with OV or NSS increased significantly $(\mathrm{P}<0.05)$ total proteins concentration by 11.6 and $17.0 \%$, respectively. Oregano and NSS increased significantly $(\mathrm{P}<0.05)$ the globulin concentration by 24.9 and $37.2 \%$, respectively (Table 4). On the other hand, albumin concentration didn't affect significantly $(\mathrm{P}<0.05)$ due to the supplement with OV or NSS.

All goats with or without OV or NSS showed higher total protein and globulin concentrations in the last three months than the first three. Similar trend was observed in globulin concentration in non treated goats while no similar trend was found in treated animals which mean that the total protein and globulin increased during the first three months to the level of last three months

It was established from these results that diet of lactating Zaraibi goats supplemented with OV or NSS improved goat's immunity, especially with NSS supplement, and restored physiologically-relevant levels of protein function. Globulin $(\mathrm{G})$ is the main component of antibodies; the increase in $\mathrm{G}$ levels indicated good immune status of the animals. It could be concluded that NSS in diets of farm animals enhance the immune status. In the same time, supplemented diets with OV or NSS decreased the factors related to heart risk (total cholesterol).

In harmony with this study Al-Gaby, 1998 found that diets supplemented with NSS caused significant $(\mathrm{P}<0.05)$ increase in serum total protein (STP) and serum phosphatases within normal ranges. Results agreed with those of Allam et al. (2007) who found that rations of lactating goats supplemented with $0.25 \mathrm{~g}$ NSS as powder/ $\mathrm{kg} \mathrm{LBW} /$ day increased significantly the concentrations of STP, albumin and G and reduced cholesterol and total lipid values in plasma of zaraibi kids. Mohamed et al. (2003) reported that STP, G and its fractions $\left(\alpha_{1}, \beta_{1}, \beta_{2}\right.$ and $\gamma_{2}$ globulins) 
concentrations increased significantly due to NSS supplemented rations of ewes. Results agreed with Awad-Allah and Gehad (2003) who found that supplementing rations of growing sheep with $2 \%$ NSS increased significantly STP and G concentrations while albumin and cholesterol concentrations were not affected significantly by NSS. On the other hand, Azab Awad-Allah (2002) reported that concentrations of STP, albumin and G were not affected significantly due to NSS supplement at the rate of $100 \mathrm{mg} / \mathrm{kg}$ body weight in Friesian calves under heat stress condition. Significant increase $(\mathrm{P}<0.05)$ in $\mathrm{G}$ concentration and insignificant $(\mathrm{P}<0.05)$ differences in STP and albumin concentrations in the blood plasma of the Ossimi lambs due to the ration supplemented with NSS was found by Salem and ElMahdy (1999).

Nigella sativa seeds increases immune function as stimulates bone marrow and immune cells and raises the interferon production, protects normal cells against cell destroying effects of viruses, destroys tumor cells and raises the number of antibodies producing B cells. In addition, NSS contains valuable unsaturated fatty acids, for example Linoleic and Gammalinolen acids get into the organism. By that it is possible to reach a synthesis of important immune regulating substances derived as from Prostaglandin (Azab Awad-Allah, 2002).

\section{Plasma content of minerals:}

Each of sodium $(\mathrm{Na})$, potassium $(\mathrm{K})$, calcium $(\mathrm{Ca})$, magnesium $(\mathrm{Mg})$, phosphor $(\mathrm{P})$ and zinc $(\mathrm{Zn})$ concentrations were not affected significantly $(\mathrm{P}<0.05)$ by diets supplemented to lactating Zaraibi goats during the hot summer season with OV (Table 6). On the other hand, diets supplemented with NSS increased significantly $(\mathrm{P}<0.05)$ each of $\mathrm{Na}(7.3 \%), \mathrm{K}(12.8 \%), \mathrm{Ca}(18.5 \%), \mathrm{P}(10.7 \%)$ and $\mathrm{Zn}(14.6 \%)$ concentrations than $\mathrm{CR}$, while $\mathrm{Mg}$ concentration was not affected.

Concentrations of $\mathrm{Na}, \mathrm{K}$, and $\mathrm{Mg}$ and $\mathrm{P}$ were higher in the last three months than the first three ones either in treated or non treated goats with OV or NSS. Zinc concentration was not affected due to experimental months either in treated or non treated goats with OV or NSS (Table ).

Salem and El-Mahdy (1999) found insignificant differences due to rations supplemented with NSS in Ca and P concentrations in the blood plasma of the Ossimi lambs.

\section{CONCLUSION}

This study recommends the supply of Oregano or crushed Nigella sativa seeds to rations of lactating goats to minimize impacts of hot conditions during summer season, increase milk yield and improve their health and physiological conditions.

\section{REFERENCES}

Agarwhal B., M.D. Kharya and R. Surivastava, 1979. Antimicrobial and Antheleminitic activity of the essential oil of Nigella sativa L.; Indian J. EXP.Biol.;17:1246.

Akgul A. and M. Kivanc, 1988. Inhibitory effects of selected Turkish spices and oregano components on some food borne fungi. Int J Food Microbiol .;6:263-268. 
Allam, S. M.; Hoda, M. EL-Hosseiny; A. M. Abdel-Gawad; S. A. EL-Saadany and A. M. M. Zeid ,1999. Medicinal Herbs and plants as feed additives for ruminants. 1- Effect of using some medicinal herbs and plants as feed additive on zaraibi goat performance. Egyptian J. Nutrition and Feeds, 2:349.

Allam, S.M.;H.M El-banna and Randa R. E. Elamie, 2007. Performance Of Zaraibi Kids Fed Diets Supplemented with medicinal herbs. Egyptian J. Nutrition and Feeds, 10(2)special issue:349-363

Al-Gaby, A. M. ,1998. Amino acid composition and biological effects of supplementing broad bean and corn proteins with Nigella sativa (black cumin) cake protein. Nahurng, 42 (5): 290-294.

A.O.A.C. ,1984. Association of Official Analytical Chemists. Official Methods of Analysis.

A.O.A.C. ,1995. Official Methods of Analysis (16'h) Edt. Association of Official Analytical Chemists; Washington; D.C.; USA.

Ayad, K. M. K. 2003. Studies on some dairy products. Ph.D. Thesis Faculty of Agriculture, Mansoura University, Egypt.

Azab Awad-Allah, M. M. ,2002. Effect of supplementation with niacin and nigella sativa seeds on Friesian calves under heat stress conditions. J. Agric. Sci., Mansoura Univ., 27(2): 791-801.

Basilico, M.Z. and J. C. Basilico ,1999. Inhibitory effects of some spice essential oils on Aspergillus ochraceus NRRL 3174 growth and ochratoxin A production. Lett Appl Microbiol . 29:238-241.

Bozin, B.; N. Mimica-Dukic ;N. Simin and G. Anackov ,2006. Characterization of the volatile composition of essential oils of some lamiaceae spices and the antimicrobial and antioxidant activities of the entire oils. J Agric Food Chem . 54:1822-1828.

Burt, S. A. and R. D. Reinders ,2003. Antibacterial activity of selected plant essential oils against Escherichia coli. Lett Appl Microbiol.;36:162-167.

Chandrosekhara, M.R.; Bhajawan, R.K.; Swaminan,M. and Subrahmanyan, V. ,1975. The use of mammalian milk food processed with foods in feeding of infants. Indian J. Chid

Chevallier, A., 1996. The Encyclopedia of medicinal plants. DK Publishing, INC. New York 10016, U.S.A.

Chorianopoulos, N.; E. Kalpoutzakis; N. Aligiannis; S. Mitaku;G. J. Nychas and S. A. Haroutounian, 2004. Essential oils of Satureja, Origanum, and Thymus species: chemical composition and antibacterial activities against foodborne pathogens . J Agric Food Chem .;5:8261-8267.

Daly, E. S. ,1998. Protective effect of cysteine and vitamin E, Crocus sativus and Nigella sativa extracts on Cisplatin-induced toxicity in rats. J. Pharm. Belg. 53 (2): 87-93.

Dimov, N. and Mineva, P.,1963. Effect of some factors on the syneresis of fresh cured and losses of solids in the whey in the processing of cows', ewes' and buffales 'milk. Dairy Sci Abst., 255

Duncan, D. B. 1955. Multiple Ranges and Multiple F- Test. Biometrics, 11: 1-42.

El-Almay H.A., M.B. Mahfouz, L.F. Hamzawy, M. El-Loly, 1991. Studies on the chemical compositin of Egyptian goats'milk fat and casein. Egypt, J. Dairy Sci. 18, (1) $195-206$. 
El-Alamy, H.A.; M.H. El - Senaity and A.M. Kholif, 1992. Manufacture of white soft cheese from goat milk supplemented with skim milk powder.J. Agric. Sci Mansoura Univ. ,17(12): 3875 - 3880.

EL-Gendy, K.M. ; A.A.Zaki; Faten F. Abou Ammo and M.F.A. EL-Gamal ,2001. Nigella sativa meal as a protein supplement in ruminant rations. Proc. $8^{\text {th }}$ Conf. Animal Nutrition, Sharm EL-Sheikh, Egypt, Egyptian J. Nutrition and Feeds (Special Issue): 1-2(Abstract).

Emara, H.M.M. ,1990. Studies on Soft Goats' Cheese. Ph. D .Thesis, Faculty of Agriculture. Mansoura University, Egypt .

Enab, A.K.M., 1993. studies on the use of Goat's Milk in chesse Production. M.S. thesis . Faculty of Agriculture Mansoura University, Egypt.

EL-Gendy, K.M. ; A.A.Zaki; Faten F. Abou Ammo and M.F.A. EL-Gamal ,2001. Nigella sativa meal as a protein supplement in ruminant rations. Proc. $8^{\text {th }}$ Conf. Animal Nutrition, Sharm EL-Sheikh, Egypt, Egyptian J. Nutrition and Feeds (Special Issue): 1-2(Abstract).

Ferdous, A. J.; S. N. Islam; M. Ashan; C. M. Hasan and Z. U. Ahmed ,1992. InVitroantibacterial activity of the volatile oil of Nigella sativa seeds against multiple drug-resistant isolates of Shigella Spp. And isolate of Vibrio Cholera and Escherichia coli, Phytotherapy Res. 6, 3:137.

Giordani, R. ; P. Regli; J. Kaloustian; C. Mikail; L. Abou and H. Portugal ,2004. Antifungal effect of various essential oils against Candida albicans. Potentiation of antifungal action of amphotericin B by essential oil from Thymus vulgaris . Phytother Res.;18: 990-995.

Habeeb, A. A. M.; S. A. EL-Saadany E. S. EL-Gohary; and M. M. El-Deeb ,2008..Improving milk yield and some physiological body functions of lactating zraibi goats under heat stress conditions of hot summer season using supplemental diet with Ginger or curcumin.(Under publication).

Ivanova, D.; D. Gerova ; T. Chervenkov and T. Yankova ,2005. Polyphenols and antioxidant capacity of Bulgarian medicinal plants . J Ethnopharmacol . 96:145150.

Khalifa, M. M. M. ,1995. Nagilla sativa seeds oil meal as a protein supplement in broiler diets. M. Sc. Thesis, Fac. Of Agric., Alexandria University, Egypt.

Koukoulitsa, C.; C. Zika; G. D. Geromichalos; V. J. Demopoulos and H. Skaltsa ,2006a. Evaluation of aldose reductase inhibition and docking studies of some secondary metabolites, isolated from Origanum vulgare L. ssp. hirtum. Bioorg. Med. Chem. 14:1653-1659.

Koukoulitsa, C.; C. Zika; G. D. Geromichalos; V. J. Demopoulos and H. Skaltsa ,2006b. Inhibitory effect of polar oregano extracts on aldose reductase and soybean lipoxygenase in vitro. Phytother. Res.; 20: 605-606.

Lawerence, A.J. ,1959: Syneresis of rennet curd . J. Dairy Technol., 14:166.

Lemhadri, A.; N. A. Zeggwagh; M. Maghrani; H. Jouad and M. Eddouks, 2004. Anti-hyperglycaemic activity of the aqueous extract of Origanum vulgare growing wild in Tafilalet region . J. Ethnopharmacol . 92:251-256.

Ling, E.R., 1963. Test Book of Dairy Chemistry. Vol. 2. (Bacterial). 3rd Ed. Champan and Hall \& TD. London. 
Livestock and Poultry Heat Stress Indices, 1990. The livestock and poultry heat stress indices for cattle, sheep and goats. Cited from the Agriculture Engineering Technology Guide, Clemson University, Clemson, SC, USA (1990).

Mehana, M.Y; A.A., El-Shazly, ;M.M., Nasr, and K.M. Ayad, 1998. Studies on Domiati cheese, 1-Yield, gross chemical composition and physical properties of curd of goats' milk as affected by feeding rations. J. Agric. Sci. Mansoura Univ., 23(11): $4949-4957$.

Mohamed, A. H.; B. E. EL-Saidy and I. A. EL-Seidi ,2003. Influence of some medicinal plants supplementation: 1- On digestibility, nutritive value, rumen fermentation and some blood biochemical parameters in sheep. Egyptian $\mathrm{J}$. Nutrition and Feeds, 6(2): 139-150.

Nair, S. C.; M. J. Salomi; B. Panikkar and K. R. Painkkar ,1991. Modulatory effects of Crocus sativus and Nigella sativa extracts on cisplatin induced toxicity in mice. J. Ethnopharmacol. 31 (1): 75-83.

N.R.C. ,1981. National Research council. Nutrient requirements of Sheep (6th Ed.). National Academy Press, Washington, D.C.

Saad, W. M. ,2001. Effect of replacing nigella sativa seed oil meal for soybean meal on performance of growing rabbits. M.Sc. Thesis. Dept. of poultry production. Fac. of Agric. Kafr. El-Sheikh. Tanta. Univ. Egypt.

Salem, F. A. and M. R. EL-Mahdy ,1999. Effect of some medicinal plants as feed additives on nutrients, digestibility, rumen fermentation, blood and carcass characteristics of sheep. The $2^{\text {nd }}$ Int. Conf. on Anim. Prod. \& Health in Semi-Arid Area, EL-Arish, North Sinai, Egypt, pp: 161-175.

SAS ,1995. SAS/ STAT User's Guide. (Version 6, $4^{\text {th }}$ Ed.). SAS Inst. Inc., Cary, NC. Snedecor, G.W. and W.G. Cochran, 1982. Statistical methods. $2^{\text {nd }}$ Ed., Iowa Univ., Press. Ames, Iwoa, USA.

Youssef, A.S. ,1989. Studies on Goats' Milk: Utilization in soft and hard cheese making. Ph.D. thesis, Faculty of Agri-Al-Azher Univ. Egypt. 


\section{تأثيراضافة البردقوش أو حبة البركة لعليقة الماعز الزرايبى الحلاب على انتاج اللبن ويعض الوظائف الفسيولوجية}

محمد الديب' عامل السعنى'، السعيد النعيمى مصطفى حبيب'، عماد صلاح حسن الجوهرى'، محمد

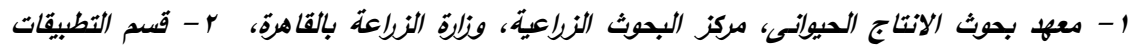

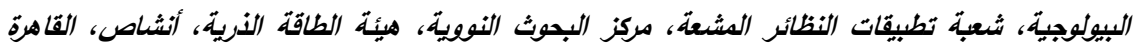

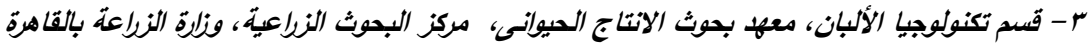

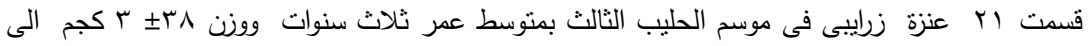

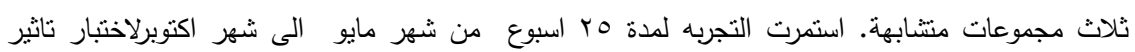

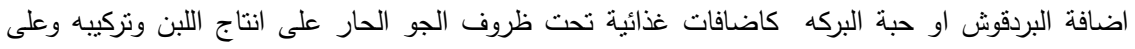

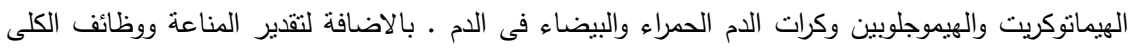

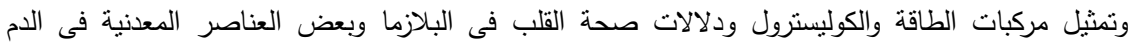

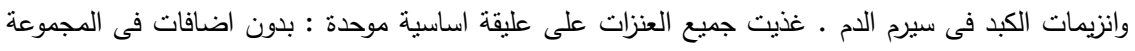

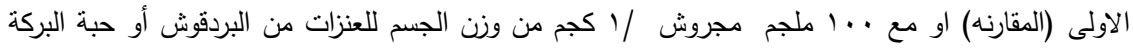

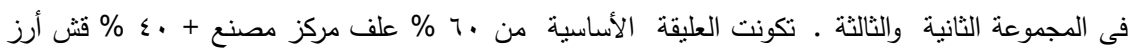

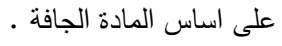
حسنت اضافة البردقوش و حبة البركة لعلائق الماعز الزرايبى الحلاب خلاد فصل الصيف معنويا

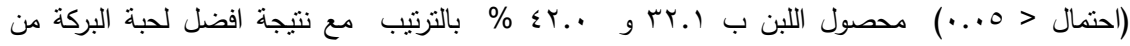

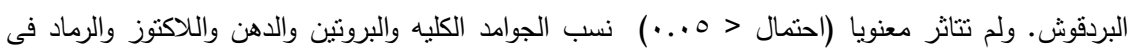

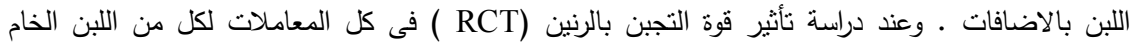

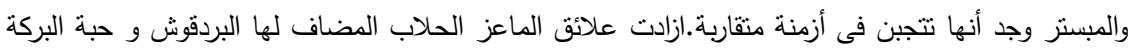

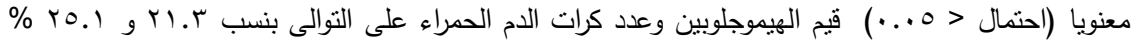

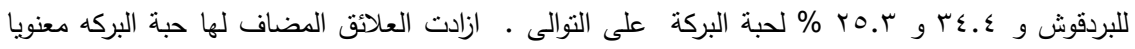

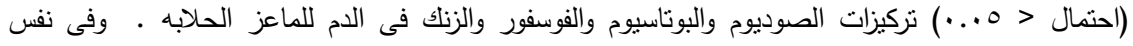

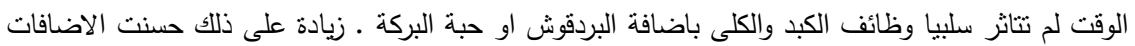

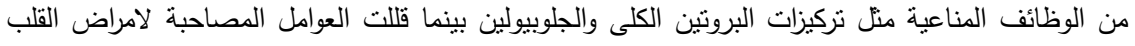

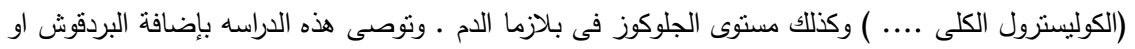




$$
\begin{aligned}
& \text { مجروش حبة البركة الى علائق الماعز الحلاب لتخفيف اثار الجو الحارأثناء فصل الصيف وزيادة انتاج اللبن }
\end{aligned}
$$

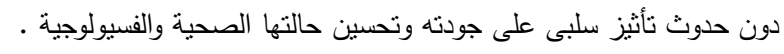

